\title{
Penggunaan Tehnologi Pendidikan Dalam Pembelajaran Jarak Jauh Bagi Siswa Tingkat SD/MI Pada Masa Pandemi Covid-19
}

\author{
Unik Hanifah Salsabila \\ Universitas Ahmad Dahlan Yogyakarta \\ unik.salsabila@pai.uad.ac.id \\ Naufal Fauzi Ramadhan \\ Universitas Ahmad Dahlan Yogyakarta \\ naufal1800031038@webmail.uad.ac.id \\ Mutia Eka Putri \\ Universitas Ahmad Dahlan Yogyakarta \\ mutia1800031116@webmail.uad.ac.id \\ Nurjannah \\ Universitas Ahmad Dahlan Yogyakarta \\ nurjannah1800031130@webmail.uad.ac.id

\section{Gita Dwi Jayanti} \\ Universitas Ahmad Dahlan Yogyakarta \\ gita1800031141@webmail.uad.ac.id
}

\begin{abstract}
Technology is very important in this day and age. There are so many fields that use technology, one of which is in the field of education. Even though Indonesia is still in a situation of the Covid-19 pandemic, education must remain number one by maximizing technology, especially in the field of communication. In this study discussed the role of technology during the distance learning process, especially for students at the SD / MI level. The formulation of the problems in this study are (1) How is the distance learning process using educational technology media for SD / MI students during the Covid-19 pandemic?; (2) What are the problems that occur in the distance learning process using educational technology media for SD / MI students during the Covid-19 pandemic?; (3) What is the solution to problems in the distance learning process by using educational technology media for SD / MI students during the Covid-19 pandemic? While the method used to answer the formulation of the problem is qualitative research with an analytic description approach, interviews and literature
\end{abstract}


Unik Hanifah Salsabila, Naufal Fauzi Ramadhan, Mutia Eka Putri, Nurjannah, Gita Dwi Jayanti

Penggunaan Teknologi Pendidikan dalam Pembelajaran Jarak Jauh

study, the focus of which is the role of technology and educational media for students at the SD / MI level during the Covid-19 pandemic. The results showed that the distance learning process was carried out using Zoom Cloud Meeting media, WhatsApp group and Google Classroom. The problem that occurs during the distance learning process is usually a signal problem that is not good and sometimes students feel bored when doing online learning so they are playing, lying down, and eating snacks. The solution that the teacher takes to overcome this problem is to provide weekend projects on Saturdays and Sundays.

Keywords: Education Technology; Online Learning; SD/MI

\begin{abstract}
Abstrak
Tehnologi merupakan hal yang sangat penting di masa sekarang ini. Banyak sekali bidang yang memanfaatkan teknologi, salah satunya di bidang pendidikan. Meskipun Indonesia masih berada dalam situasi pandemi Covid-19, namun pendidikan harus tetap di nomor satukan dengan memaksimalkan teknologi khususnya bidang komunikasi. Di dalam penelitian ini dibahas mengenai peran teknologi selama proses pembelajaran jarak jauh terutama bagi peserta didik pada tingkat SD/ MI. Rumusan masalah dalam penelitian ini yaitu (1) Bagaimana proses pembelajaran jarak jauh dengan menggunakan media teknologi pendidikan bagi Siswa SD/MI di Masa pandemi Covid-19?; (2) Apa saja permasalah-permasalahan yang terjadi dalam proses pembelajaran jarak jauh dengan menggunakan media teknologi pendidikan bagi Siswa SD/MI di Masa pandemi Covid-19?; (3) Bagaimana solusi permasalahan dalam proses pembelajaran jarak jauh dengan menggunakan media teknologi pendidikan bagi Siswa SD/MI di Masa pandemi Covid-19? Metode Penelitian yang digunakan adalah penelitian Kualitatif dengan pendekatan deskripsi analitik, wawancara dan studi literatur kepustakaan. Hasil penelitian ini menunjukkan (1) proses pembelajaran jarak jauh dilakukan dengan menggunakan media Zoom Cloud Meeting, Whatsapp grup dan Google Classroom. (2) Permasalahan yang terjadi pada saat proses pembelajaran jarak jauh adalah adanya kendala sinyal yang kurang bagus dan terkadang siswa merasa bosan ketika sedang melakukan pembelajaran daring sehingga mereka sambil bermain, tiduran, dan memakan cemilan. (3) Solusi yang dilakukan oleh guru untuk mengatasi permasalahan tersebut adalah dengan memberi weekend project di hari Sabtu dan Ahad.
\end{abstract}

Kata Kunci: Tehnologi Pendidikan; Pembelajaran Daring; SD/MI 


\section{PENDAHULUAN}

Pendidikan merupakan proses terpenting bagi kehidupan manusia, karena pendidikan menjadi salah satu komponen penting bagi kita dalam mengarungi kehidupan di dunia ini. Tak hanya itu, teknologi juga merupakan faktor pendukung dari berjalannya proses pendidikan bagi manusia, keduanya saling berhubungan satu sama lain dengan melakukanperbaikan-perbaikan yang baik kedepannya dengan mengikuti zaman. Bisa kita lihat bersama bahwa teknologi dan media pembelajaran merupakan hal pendukung dalam pembelajaran, dan di masing-masing tingkat sekolah pun berbeda-beda dalam pemenuhan teknologi dan media pembelajarannya. Menurut Karo-karo dan rohani $^{1}$, bagi pengajar, menggunakan media pembelajaran dalam prosesnya dapat berubah konsep abstrak menjadi konkrit dan selain itu media pembelajaran dapat menarik minat dan motivasi siswa dalam pembelajaran sehingga mereka belajar aktif.

Tentu tujuan ataupun goals dari teknologi dan media pembelajaran ini tergantung dengan tujuan pembelajaran dari masing-masing tingkat, dan peneliti akan menitik fokuskan untuk membahas di tingkat SD/ MI, bagaimana teknologi yang digunakan, peran media pembelajarannya, dan permasalahan yang timbul dari berjalannya proses pembelajaran tersebutserta solusi-solusi apa saja yang dilakukan untuk mengatasi permasalahan yang terjadi. Di masa pandemi Covid-19 ini tentu memiliki perbedaan dan goals yang berbeda dibanding dengan di era normal sebelum pandemi, yang tentunya teknologi sangat dibutuhkan dan sangat berperan dalam proses pendidikan di masa pandemi Covid-19 seperti ini. Semua elemen sekolah dituntut untuk memaksimalkan teknologi yang ada guna untuk mencapai tujuan pendidikan bersama baik dari guru, komponen sekolah, orang tua, hingga peserta didik.

\footnotetext{
${ }^{1}$ Isran Rasyid Karo-Karo S dan Rohani, Manfaat Media Dalam Pembelajaran, Jurnal AXIOM: Vol. VII, No. 1, Januari-Juni (2018). 91.
} 
Unik Hanifah Salsabila, Naufal Fauzi Ramadhan, Mutia Eka Putri, Nurjannah, Gita Dwi Jayanti

Penggunaan Teknologi Pendidikan dalam Pembelajaran Jarak Jauh

Dalam penelitian Ely Satiyasih Rosali disebutkan bahwa selama masa pandemi ini, pembelajaran dilaksanakan secara online atau daring. aplikasi yang biasanya dipakai dalam pembelajaran yaitu Google Classroom, Youtube, dan platform lain yaitu quizizz. pembelajaran daring yang dilakukan memang tidak seefektif pembelajaran tatap muka karena banyak kendala yang dihadapi seperti sulitnya koneksi internet dan ketersediaan perangkat seperti laptop. ${ }^{2}$ Selain Ely, pada penelitian Briliannur Dwi C dkk menjelaskan bahwa pembelajaran daring mempunyai dua tipe yang berbeda yaitu Synchronous yang berarti waktu yang sama dan Asynchronous yang artinya tidak pada waktu yang sama. ${ }^{3}$ Ini berarti waktu pembelajaran daring lebih fleksibel.

Dari penelitian-penelitian tersebut membuat peneliti semakin ingin mengetahui bagaimana penggunaan teknologi pendidikan dalam pembelajaran bagi peserta didik di tingkat Sekolah Dasar (SD) ataupun Madrasah Ibtidaiyah (MI) selama pandemi Covid-19. Selamanya peran seorang pendidik/ guru tidak akan tergantikan oleh teknologi. Oleh karena itu, butuh pembiasaan maupun adaptasi baik guru sebagai pengajar maupun siswa sebagai pembelajar agar proses pembelajaran jarak jauh yang mengandalkan teknologi dan media pembelajaran di era pandemi seperti ini berjalan dengan lancar.

\section{METODE PENELITIAN}

Metode penelitian ini menggunakan pendekatan deskriptif analitik, studi literatur kepustakaan dan melakukan wawancara dengan salah satu guru MI di Balikpapan yaitu Ibu Kholiq Rahmawati dan juga orang tua dari siswa yang mana fokus pertanyaannya terkait peran teknologi dan media pendidikan bagi siswa tingkat SD/ MI di masa pandemi Covid-19. Dalam

\footnotetext{
${ }^{2}$ Ely Satiyasih Rosali, Aktifitas Pembelajaran Daring Pada Masa Pandemi Covid-19 di Jurusan Pendidikan Geografi Universitas Siliwangi Tasikmalaya, Geography Science Education Journal (GEOSEE), Vol. 1, No.1 Juni (2020). 26.

${ }^{3}$ Briliannur Dwi C dkk, Analisis Keefektifan Pembelajaran Online di Masa Pandemi Covid-19, Jurnal MAHAGURU: Jurnal Pendidikan Guru Sekolah Dasa, Vol. 2, No 1 (2020), 34.
} 
pendekatan deskriptif analitik akan dijelaskan bagaimana suatu data disajikan supaya informasi yang terkandung didalamnya dapat diterima secara jelas oleh orang lain. Deskriptif analitik menjelaskan suatu hal yang diteliti melalui data dari sampel yang sudah dipilih sebelumnya. Teknik pengumpulan data diambil dari studi kepustakaan yang diperoleh dari beberapa jurnal, buku, dan pendapat yang berkaitan dengan teknologi, media pembelajaran, dan kondisi peserta didik saat menjalani pembelajaran jarak jauh ini. Dari studi literatur dan deskriptif analitik ini kemudian dicocokkan dengan data wawancara yang peneliti lakukan kepada responden yang terdiri dari guru SD/MI, dan orang tua murid yang berdampak langsung terhadap anak nya yang menjalani proses pembelajaran jarak jauh ini agar selanjutnya dari metode penelitian yang peneliti jalankan dapat menjadi acuan yang baik untuk hasil yang dituju oleh peneliti dan dikembangkan menjadi data yang signifikan lalu ditemukan korelasi yang real terjadi pada pembelajaran dalam jaringan (daring) ini. Dalam memeriksa keabsahan data menggunakan dua cara, yakni: Triangulasi dan Diskusi dengan teman sejawat.

\section{HASIL DAN PEMBAHASAN TEMUAN}

\section{HASIL TEMUAN}

Hasil temuan dari data jawaban para wali murid dan guru, sesuai dengan pertanyaan-pertanyaan yang dibuat. Dari hasil temuan yang didapatkan menyatakan bahwa sebagian besar guru dan orang tua merasakan bahwa penggunaan teknologi memiliki pengaruh yang besar dalam proses pembelajaran daring. Berikut ini deskripsikan jawaban pertanyaan dari masing-masing responden:

Hal ini sebagaimana wawancara peneliti dengan Kholiq Rahmawati, beliau menjelasakan:

"Media yang dipakai yaitu Zoom Cloud Meeting, Google Classroom, dan Whatsapp Group. Media tersebut sampai saat ini (selama 7 bulan) masih efektif untuk digunakan meskipun berbeda dari pembelajaran offline. respon siswa ketika sedang pembelajaran daring dengan memberikan 
Unik Hanifah Salsabila, Naufal Fauzi Ramadhan, Mutia Eka Putri, Nurjannah, Gita Dwi Jayanti

Penggunaan Teknologi Pendidikan dalam Pembelajaran Jarak Jauh

respon yang baik dan antusias walaupun sering terjadi kebosanan terutama siswa kelas I. Terkadang mereka sambil tiduran, mainan, dan ngemil makanan. Upaya yang dilakukan yaitu dengan agenda weekend project di hari sabtu dan ahad. Dalam pelaksanaan pembelajaran dipastikan setiap wali kelas mengingatkan para wali murid melalui grup Whatsapp kelas untuk menyiapkan kondisi anak untuk belajar. Setiap pukul 07.00 pagi, murid sudah bisa masuk di room Zoom yang sudah disediakan 5 menit sebelum pembelajaran dimulai" ".

Lebih lanjut Ibu Kholiq Rohmawati menjelaskan:

"Dalam pembelajaran daring, orang tua dan pihak sekolah mengambil ibrah/manfaat untuk pendampingan anak selama belajar terutama siswa di kelas level bawah, kelas I, II, III. Biasanya guru mengirimkan intisari pembelajaran melalui Google Classroom, kemudian wali murid membantu anaknya untuk memahami kembali materi yang disampaikan oleh guru. Kemudian jenis media yang digunakan berupa media audio, visual, dan audio visual. Semua digunakan untuk efektifitas kegiatan belajar mengajar"s.

Sedangkan menurut orang tua siswa Ibu Dyah Astuti Ningrum

Kumalasary, menjelaskan kepada peneliti:

"karena tahun pembelajaran anak saya memang disaat Covid jadi pembelajaran dari awal hanya dengan daring. Alhamdulillah sampai saat ini masih semangat belajar walaupun belajar online. Iya, mengingatkan anak kalau ada tugas yang dikirim dari guru, mengecek tugas anak sebelum disetor ke gurunya", 6 .

lebih lanjut, Ibu Bredha Velatiani menjelasakan kepada peneliti sebagai berikut:

"iya sangat penting, semua pelajaran saya harus tahu supaya bisa menjelaskan kepada anak. yang tidak terlalu sering, bertanya hanya sebatas lingkup pelajaran saja. hasil belajarnya baru pertama kali dan saya kurang puas karena bukan murni 100\% hasil kerja anak"

Teknologi merasuk kedalam lingkungan manusia dari sejarah-sejarah kemanusiaan. ${ }^{8}$ Teknologi merupakan kegiatan yang dapat mengubah lingkungan hidup seseorang. Kata Teknologi memiliki asal kata dari bahasa Latin texer yang artinya membangun atau menyusun. Pada dasarnya, kata

\footnotetext{
${ }^{4}$ Kholiq Rahmawati. Wawancara, Balikpapan, 28 Oktober 2020.

${ }^{5}$ Kholiq Rahmawati. Wawancara, Balikpapan, 28 Oktober 2020

${ }^{6}$ Dyah Astuti Ningrum Kumalasary. Wawancara, Balikpapan, 28 Oktober 2020.

${ }^{7}$ BredhaVelatiani.Wawancara, Balikpapan, 28 Oktober 2020.

${ }^{8}$ Abdullah Burhanudin. Menanti Kemakmuran Negri, (Jakarta: PT. Gramedia Pustaka Utama, 2006), 2-4.
} 
teknologi memang tidak ada batasan pada penggunaan mesin. Walaupun kata tersebut sering digunakan dalam kehidupan sehari-hari, namun kata tersebut menjadi tidak asing didengar oleh manusia. ${ }^{9}$ Dengan keadaan yang sedang mewabahnya pandemi Covid-19 tentunya teknologi sangat bermanfaat bagi peserta didik maupun pendidik. Karena tidak ada pilihan lain kecuali dengan adanya teknologi. Contohnya: hp, laptop, televisi, dan produk teknologi lainnya. Maka daripada itu teknologi saat ini bukanlah hal yang tertinggal namun sudah menjadi kebutuhan sehari-hari bagi manusia dalam proses pendidikan maupun hal lainnya.

Berbagai macam peran teknologi pembelajaran bisa kita rasakan saat ini, yaitu:

1. Dengan adanya teknologi maka bisa mengurangi kegiatan yang mengumpulkan banyak orang.

Di masa pandemi tentunya pemerintah menghimbau semua orang agar tidak melakukan kegiatan yang mengumpulkan banyak orang. Melalui teknologi kita tetap bisa sekolah dan bekerja seperti biasanya meskipun melalui ruang virtual dan tentunya ada hal-hal yang harus disesuaikan.

2. Membantu siswa memperoleh materi belajar dari berbagai sumber.

Perkembangan teknologi yang sangat pesat sangat memungkinkan siswa untuk dapat mengakses informasi dan materi belajar dari berbagai sumber sehingga tidak hanya bergantung kepada guru.

Ada beberapa pendapat tentang teknologi pendidikan:

1. Istilah teknologi pendidikan secara umum dapat diartikan sebagai teknologi komunikasi, teknologi penerapan, untuk kegiatan dalam pendidikan dalam proses belajar mengajar. ${ }^{10}$

2. Teknologi pendidikan juga memberikan pembuktian strategi yang efektif dan efisien. Sebelum digunakan dalam skala nasional, teknologi

\footnotetext{
${ }^{9}$ Rusman, dkk. Pembelajaran Berbasis Teknologi Informasi dan Komunikasi, Mengembangkan Profesionalitas Guru, ed.1, cet. Ke-4, (Jakarta: Rajawali Pers, 2015), 78.

${ }^{10}$ Nasution, Teknologi Pendidikan, (Jakarta: Bumi Aksara, 2005), 1-2.
} 
Unik Hanifah Salsabila, Naufal Fauzi Ramadhan, Mutia Eka Putri, Nurjannah, Gita Dwi Jayanti

Penggunaan Teknologi Pendidikan dalam Pembelajaran Jarak Jauh

pendidikan terus mencoba strategi secara berkala, sehingga dapat memberikan pembuktian yang efektif.

3. Strategi-strategi tersebut hanya terfokus pada rangkaian interaksi antara siswa dengan belajar dalam skala yang luas. Sehingga pendidik juga memiliki interaksi kepada siswa agar dapat mencapai pembelajaran yang telah ditentukan. Pengertian tersebut dapat memberikan keyakinan dalam memberikan solusi dalam memecahkan permasalahan dalam konsepkonsep yang telah dijelaskan diatas.

Teknologi Pendidikan tentunya sangat berkaitan dengan proses belajar yang menggunakan pengajaran audio, visual atau bisa memadukan keduanya menjadi audio visual. Seiring berkembangnya waktu dan peradaban, teknologi pendidikan sangat berkembang, hal ini tentunya sangat baik bagi dunia pendidikan dan dapat membantu mengatasi masalahmasalah yang terjadi dalam dunia pendidikan. Tidak hanya teknologi, guru yang memberikan materi juga memberikan sumbangsih yang besar bagi kemajuan pendidikan. Pendidikan merupakan proses dimana seorang manusia dibentuk karakternya serta membuat mereka menjadi manusia yang terdidik dan mempunyai keunggulan dalam dirinya. Dengan penggunaan teknologi ini lah yang akan membantu guru sebagai pengajar untuk mencapai hal-hal tersebut. Memang tidak mudah tetapi dengan dukungan semua pihak maka hal tersebut bisa dicapai.

Di masa pandemi, teknologi dalam bidang pendidikan sangat berperan penting. Demi menjaga kesehatan bersama, seluruh masyarakat terutama Indonesia memilih proses pembelajaran melalui online. Pembelajaran secara daring memang bukan hal yang mudah untuk dilaksanakan namun hal ini harus dilaksanakan agar proses belajar mengajar tetap berjalan dengan baik walaupun terdapat banyak kendala seperti susahnya jaringan, pembelajaran secara daring pun tetap berjalan dengan semestinya. Artinya teknologi pendidikan dapat membantu peserta didik untuk dapat mengerti atau memahami pelajaran sesuai materi-materi yang telah diberikan oleh 
pendidik. Tentunya saat ini teknologi pendidikan menjadi sorotan utama bagi peserta didik.

\section{Media Pembelajaran}

Pada dasarnya, media berasal dari bahasa Latin medius yang dapat diartikan "tengah", "perantara" atau "pengantar". Lain dari itu, Dalam bahasa Arab menunjukkan bahwa media adalah suatu perantara ataupun pengantar pesan dari pengirim kepada penerima pesan. ${ }^{11}$ Dari kata tersebut maka bisa kita simpulkan bahwa media pembelajaran merupakan perantara atau alat bantu yang digunakan oleh seseorang agar pesan yang disampaikan bisa diterima dengan baik dimana pesan tersebut disampaikan pada saat proses belajar. Kita tentu sudah tidak asing dengan istilah media pembelajaran. Dalam dunia pendidikan khususnya pada saat pembelajaran tentunya terjadi interaksi atau hubungan timbal balik antara guru dan siswa sehingga membutuhkan media belajar yang bisa membantu guru dalam menyampaikan materi pembelajaran serta bisa memudahkan siswa dalam memahami materi yang diajarkan.

Media pembelajaran disebut sebagai suatu alat bantu dalam proses kegiatan belajar mengajar (KBM) untuk merangsang pikiran, perasaan, perhatian, dan kemampuan maupun keterampilan pembelajar sehingga dapat memberikan dorongan demi terlaksananya proses belajar. ${ }^{12}$ Kriteria yang pertama dan utama dalam melakukan suatu pemilihan media, yaitu bahwa media harus disesuaikan dengan tujuan pembelajaran yang ada atau kompetensi yang hendak diwujudkan sehingga kemampuan siswa dapat dikeluarkan seluruhnya dan hasil belajarnya pun menjadi maksimal. ${ }^{13}$ Terdapat berbagai media yang bisa dipakai dalam pembelajaran. Misalnya media pembelajaran berupa video, rekaman suara, gambar-gambar yang

\footnotetext{
${ }^{11}$ Azhar Arsyad, Media Pembelajaran, (Jakarta: PT. RajaGrafindo Persada, 2013), 3.

12 Talizaro Tafonao, Peranan Media Pembelajaran Dalam Meningkatkan Minat Belajar Mahasiswa, Jurnal Komunikasi Pendidikan, Vol.2 No.2, Juli 2018, 105.

${ }^{13}$ Umar, MEDIA PENDIDIKAN: Peran dan Fungsinya dalam Pembelajaran, Jurnal Tarbawiyah, Vol. 11 N. 1 Edisi Januari-Juli 2014, 134.
} 
Unik Hanifah Salsabila, Naufal Fauzi Ramadhan, Mutia Eka Putri, Nurjannah, Gita Dwi Jayanti

Penggunaan Teknologi Pendidikan dalam Pembelajaran Jarak Jauh

berkaitan dengan materi, serta buku-buku yang menunjang pembelajaran. Media pembelajaran dipilih dengan tepat akan membuat siswa semakin paham apa yang disampaikan oleh guru. Seorang pendidik juga dapat menciptakan media pembelajaran sendiri yang sekiranya akan menarik perhatian siswa. Semakin menarik dan kreatif media pembelajarannya tentu siswa akan lebih banyak memperhatikan guru saat sedang menjelaskan materi.

Masa pandemi adalah masa dimana teknologi sangat berperan besar di berbagai bidang terutama bidang pendidikan. Demi melakukan upaya pemutusan mata rantai virus Corona maka pemerintah menerapkan kebijakan bahwa masyarakat dilarang untuk mengadakan kegiatan diluar rumah dengan jumlah orang yang banyak. Ketika pemerintah menerapkan Work From Home dan School From Home maka disitulah teknologi menjadi sangat penting. Hal ini tentunya memberikan pengalaman baru bagi siswa karena biasanya mereka melakukan pembelajaran secara tatap muka. Karena melakukan pembelajaran daring, maka guru harus mengubah media pembelajaran agar menyesuaikan keadaan.Guru dan siswa sadar bahwa meskipun sedang kondisi pandemi, kegiatan pembelajaran harus tetap berjalan. Penggunaan teknologi tentunya tidak terikat pada ruang dan waktu sehingga pembelajaran bisa dilakukan kapan saja dan dimana saja atau bisa dikatakan pembelajaran lebih fleksibel. Agar tetap bisa berinteraksi dengan siswa, guru dapat menggunakan video conference saat proses pembelajaran. Teknologi seperti ini sangat membantu guru untuk melakukan pembelajaran jarak jauh.

Teknologi didalam lingkup pendidikan khususnya pelaksanaan kegiatan belajar-mengajar, seperti yang sering dilakukan oleh guru maupun dosen, yaitu mengkombinasikan alat teknologi di dalamnya. Artinya, dalam pengaplikasian media pembelajaran sekaligus teknologi dapat membantu peserta didik untuk paham akan materi pelajaran yang disampaikan oleh 
pendidik. ${ }^{14}$ Belakangan ini, tentunya teknologi sudah banyak digunakan di dunia pendidikan sebagai media belajar, dan apabila tidak mengikuti perkembangan teknologi maka bisa-bisa kita tertinggal informasi.

Peran media pembelajaran di masa pandemi:

1. Membantu guru ketika menyampaikan materi pembelajaran yang dirasa sulit dan rumit.

2. Media pembelajaran yang digunakan akan lebih memudahkan guru ketika menyampaikan materi yang sulit dipahami siswa.

3. Membuat waktu lebih efisien.

4. Ketika menggunakan media pembelajaran yang tepat maka waktu yang digunakan selama proses belajar akan lebih efektif dan efisien karena siswa lebih cepat menangkap materi yang diajarkan.

5. Membuat desain kegiatan sekolah daring tidak membosankan.

6. Membantu guru dalam menghemat tenaga.

7. Membuat pembelajaran daring semakin menarik dan interaktif

Kreativitas guru dalam membuat media pembelajaran akan membuat proses belajar lebih menyenangkan dan akan terjadi interaksi antara guru dengan murid sehingga proses belajar berjalan dua arah.

8. Membantu siswa lebih memahami materi

Media pembelajaran berperan untuk memperjelas materi yang diajarkan. Saat materi sudah jelas maka siswa akan dengan mudah menangkap dan memahami materi.

9. Memudahkan guru dalam mencapai tujuan pembelajaran

Penggunaan media pembelajaran akan membuat siswa lebih paham materi, siswa tidak salah tafsir dengan materi yang diajarkan, pembelajaran lebih menarik dan lain-lain.

Di Sekolah Tahfidz Plus (STP) SD Khoiru Ummah pembelajaran daring dilakukan menggunakan aplikasi Zoom Cloud Meeting dan presensi

\footnotetext{
${ }^{14}$ Talizaro Tafonao, Peranan Media Pembelajaran Dalam Meningkatkan Minat Belajar Mahasiswa, Jurnal Komunikasi Pendidikan, Vol.2 No.2, Juli 2018, 110.
} 
Unik Hanifah Salsabila, Naufal Fauzi Ramadhan, Mutia Eka Putri, Nurjannah, Gita Dwi Jayanti

Penggunaan Teknologi Pendidikan dalam Pembelajaran Jarak Jauh

akan dilakukan melalui Google Classroom. Lima menit sebelum pembelajaran dimulai, guru akan mengingatkan kepada wali murid yang ada di grup untuk mempersiapkan dan mendampingi sang anak ketika sedang belajar daring. Media pembelajaran yang dipakai berupa media audio, visual, dan audio visual. Semua digunakan untuk efektifitas kegiatan belajar mengajar. Ketika ada rangkuman atau intisari dari pembelajaran, guru akan mengirimkannya melalui media google classroom. Orang tua diharapkan dapat membantu anaknya untuk memahami dan merefresh kembali apa yang disampaikan oleh guru. Proses pendampingan ini sangat penting terutama bagi siswa yang masih duduk dikelas I, II, dan III. ${ }^{15}$

Komunikasi antara guru dan orangtua selama pembelajaran daring bisa berjalan dengan lancar berkat tersedianya teknologi. Guru dapat menginfokan hal-hal mengenai proses belajar mengajar melalui grup kelas. Selain itu guru bisa selalu mengingatkan orang tua untuk mengawasi anakanaknya ketika belajar di rumah. Teknologi dan media pembelajaran tentu sangat berkaitan dengan proses pembelajaran. Keduanya sangat membantu guru dalam proses pembelajaran pembelajaran daring. Adanya teknologi sangat memungkinkan pelaksanaan pembelajaran jarak jauh seperti sekarang ini. Peningkatan kualitas pendidikan di masa mendatang memerlukan sistem informasi dan teknologi informasi yang tidak hanya berfungsi sebagai sarana pendukung, melainkan lebih dari itu sehingga dapat berfungsi sebagai senjata utama dalam mendukung keberhasilan bidang pendidikan serta menjadikan pendidikan ini mampu bersaing di pasar global. $^{16}$

\footnotetext{
${ }^{15}$ Kholiq Rahmawati, Wawancara, Balikpapan 28 Oktober 2020.

${ }^{16}$ Haris Budiman, Peran Teknologi Informasi Dan Komunikasi Dalam Pendidikan, AlTadzkiyyah: Jurnal Pendidikan Islam, Volume 8 No. I, (2017), 35.
} 


\section{PEMBAHASAN TEMUAN}

\section{Proses Pembelajaran Jarak Jauh Pembelajaran Jarak Jauh di Masa Pandemi Covid-19}

Pembelajaran jarak jauh adalah pembelajaran ketika siswa dan pengajar tidak selalu hadir secara fisik secara bersamaan di sekolah. Pembelajaran jarak jauh disebut sebagai suatu sistem pembelajaran yang tidak dapat berlangsung dalam satu ruangan dalam artian tidak berada pada tempat yang sama dan tidak terdapat interaksi/ komunikasi tatap muka secara langsung sehingga memerlukan media digital yang digunakan oleh pengajar dan para pembelajar. ${ }^{17}$ Pembelajaran jarak jauh dilakukan dengan menggunakan aplikasi belajar seperti Google Classroom, Edmodo, atau melalui video conference seperti Zoom Cloud Meeting dan Google Meet. Semuanya menyesuaikan keadaan agar tidak terlalu memberatkan guru dan siswa.Sehubungan dengan keadaan tersebut, pembelajaran jarak jauh yang dilakukan di Sekolah Tahfidz Plus (STP) SD Khoiru Ummah menggunakan Zoom Cloud Meeting, Classroom, WhatsApp group. Layanan olah pesan ini dipilih karena biasa dipakai oleh siswa serta memungkinkan pengguna untuk mengirim tugas, pesan teks dan pesan suara, melakukan panggilan suara dan video, berbagi gambar, video, dokumen, lokasi pengguna, dan media lainnya. Penyampaian materi langsung oleh guru via Zoom Cloud Meeting hanya pelajaran agama saja yang mana pelaksanaan proses KBM PAI hanya dilakukan satu minggu sekali.

Untuk pembelajaran tematik, anak diberi perintah belajar via Youtube, kemudian pendidik memberikan penjelasan secara singkat melalui voice note Whatsapp group, dimana orang tua juga dituntut untuk memahami materi yang telah diberikan. Untuk pembelajaran PJOK,terdapat tugas-tugas praktik di Google Classroom. Sehingga orang tua/ wali siswa yang menjadi guru olahraga dalam praktik. Dari segi keamanan peserta didik dipantau

\footnotetext{
${ }^{17}$ Munir. Pembelajaran Jarak Jauh Berbasis Teknologi Informasi dan Komunikasi. (Bandung: Alfabeta. 2009), 1-16.
} 
Unik Hanifah Salsabila, Naufal Fauzi Ramadhan, Mutia Eka Putri, Nurjannah, Gita Dwi Jayanti

Penggunaan Teknologi Pendidikan dalam Pembelajaran Jarak Jauh

secara terus menerus. Waktu yang disepakati oleh pengajar dan siswa ialah pada pagi-siang hari seperti waktu sekolah pada umumnya. Kesepakatan waktu ini diambil agar proses pembelajaran tetap mempertahankan sisi interaksi secara langsung. Pelaksanaan dilakukan dengan memberi bahan panduan kegiatan yang dibagikan setiap hari guna dilaksanakan kemudian hasilnya dilaporkan secara pribadi.

Pada konteks masa pandemi Covid-19, Pembelajaran jarak jauh dilaksanakan sebagai bentuk upaya pencegahan penyebaran virus Covid-19. Pada protokol pencegahan penyebaran virus Covid-19 disebutkan bahwa masyarakat diminta untuk menghindari kerumunan atau pengumpulan orang. Pada konteks pembelajaran di Sekolah, pengumpulan orang dan interaksi langsung antara civitas akademika (guru, siswa, dosen, mahasiswa, dan civitas akademik lainnya) dalam satu lingkungan sekolah bisa saja menjadi sarana yang memiliki potensi besarterjadinya penyebaran virus Covid-19. Oleh karena itu, pembelajaran jarak jauh menjadi upaya penting dalam rangka menekan penyebaran virus secara luas, khususnya di kalangan pengajar dan pembelajar.

\section{Permasalahan Yang Terjadi Saat Pembelajaran Jarak Jauh di Masa Pandemi Covid-19}

Selama pembelajaran daring yang memanfaatkan teknologi khususnya aplikasi edukasi membutuhkan jaringan/ sinyal internet yang kuat. ${ }^{18}$ Pembelajaraan dapat terhambat akibat jaringan internet yang sulit didapat untuk beberapa wilayah yang kondisi demografinya di pelosok daerah. Sehingga guru dapat melaksanakan pembelajaran yang lebih bersifat asinkron, agar siswa tetap dapat mengakses materi pelajaran dan mengumpulkan tugas ketika sudah mendapati sinyal yang bagus dan lancar. Selain itu, guru melakukan home visit ke rumah-rumah siswa dalam jangka waktu tertentu tergantung kebijakan sekolah. Hal ini dilakukan dalam

\footnotetext{
${ }^{18}$ Henry Aditia Rigianti, Kendala Pembelajaran Daring Guru Sekolah Dasar di Kabupaten Banjarnegara, Jurnal Elementary School, Vol.7 No.2, Juli (2020), 299.
} 
rangka memantau kondisi anak dan mengevaluasi proses pembelajaran yang telah dilaksanakan selama sepekan secara virtual.

Guru, materi, dan metode merupakan sebagian dari komponen dalam pembelajaran yang sangat penting bagi siswa. ${ }^{19}$ Hal tersebut menyiratkan bahwa ketika pembelajaran guru harus menyesuaikan materi dan metode yang sesuai untuk diterapkan ketika pembelajaran jarak jauh menggunakan media digital kepada siswa agar dapat nyaman, tidak mudah bosan, dan siswa dapat menyerap materi yang disampaikan dengan baik. Karena walau bagaimanapun, perubahan sistem pembelajaran ini akan berdampak pada kemampuan siswa menangkap dan menyerap materi pelajaran yang berbeda dari sebelumnya ketika pembelajaran luring. Dapat dipahami dan dimaklumi atas kemampuan daya serap siswa dalam mempelajari materi berbeda-beda, namun guru harus tetap mengoptimalkan strategi-strategi mengajar yang baik. Hasil pembelajaran anak selama pembelajaran daring ini menurun dibandingkan pembelajaran luring. Dikarenakan tugas yang terlalu banyak diberikan oleh guru, sehingga orang tua peserta didik kewalahan dengan keadaan.

Ketika awal pembelajaran daring, peserta didik merasa terkejut dengan keadaan dikarenakan banyaknya problematika terkait banyaknya penggunaan kuota internet, ditambah dengan keadaan orang tua peserta didik yang mana keadaan Covid-19 ini juga berdampak pada penghasilan mereka. Kemudian kendala lainnya adalah handphone atau perangkat pendukung lain kurang memadai dalam keluarga, hal ini merupakan problematika dalam proses pembelajaran daring. Ini terjadi di 3 bulan awal terjadinya Covid-19. Namun 3 bulan terakhir ini terjadi peningkatan interaksi peserta didik dengan guru dalam pembelajaran secara daring. Terkadang peserta didik khususnya siswa sekolah dasar yang mudah hilang konsentrasi ketika pembelajaran tatap muka langsung, terlebih jika

\footnotetext{
${ }^{19}$ H.M. Jufri Dolong, Teknik Analisis Dalam Komponen Pembelajaran, Jurnal Inspiratif Pendidikan, Vol. 5 No. 2, Juli-Desember, (2016), 299.
} 
Unik Hanifah Salsabila, Naufal Fauzi Ramadhan, Mutia Eka Putri, Nurjannah, Gita Dwi Jayanti

Penggunaan Teknologi Pendidikan dalam Pembelajaran Jarak Jauh

dilaksanakan pembelajaran jarak jauh, tentunya akan lebih kacau dan menjadi tidak efektif. Hal tersebut menjadikan guru membuat aturan khusus selama pembelajaran daring agar siswa lebih relax dan enjoy mengikuti pelajaran karena siswa kelas I masih berada pada tahap adaptasi dari masa Tkdan tentunya tetap dalam pantauan dan bantuan orang tua/ wali ataupun orang terdekatnya. Namun, berdasar realita yang ada, telah terjadi di Gowa, Sulawesi Selatan bahwa terdapat kasus siswi bunuh diri karena diduga depresi akibat tidak sanggup ketika dihadapkan pada tugas yang banyak selama pembelajaran jarak jauh ini. ${ }^{20}$ Selama Study From Home, sosok orang tua memiliki andil lebih besar dalam memotivasi dan membimbing anak dalam belajar. Orang tua siswa perlu paham dan memastikan bahwa selama di rumah, anak tetap fokus pada kegiatan belajar yang berlangsung sehingga tidak menyalahgunakan waktu dan kesempatan itu untuk bermain game online dan bersantai.

\section{Solusi Yang Dilakukan Untuk Mengatasi Permasalahan Dalam Pembelajaran Jarak Jauh di Masa Pandemic Covid-19}

Dalam masa-masa seperti ini siswa semangat dan selera siswa untuk belajar relative labil. Disitulah perhatian dan motivasi dari orang tua dapat berpengaruh besar pada mindset dalam diri anak, sehingga anak akan memiliki rasa tanggung jawab yang lebih dan selalu bertekad untuk belajar dengan baik agar tidak mengecewakan. Kebijakan ini juga memberikan dampak positif bagi sebagian orang tua dan anak, karena keduanya dapat menjadi lebih dekat dan akrab.Keberhasilan anak bergantung pada perlakuan orang tua terhadap anak tersebut. Relasi antara guru, orang tua siswa, dan siswa harus saling berkesinambungan dengan menjalin komunikasi yang baik dan saling bertukar informasi terkait perkembangan belajar anak. Dengan sosialisasi antara pihak sekolah dengan orang tua/ wali

\footnotetext{
${ }^{20}$ Sania Mashabi, Siswi Bunuh Diri Diduga Depresi karena Tugas Sekolah Daring, KPAISuratiKemendikbuddalamhttps://nasional.kompas.com/read/2020/10/23/15110441/sis wi-bunuh-diri-diduga-depresi-karena-tugas-sekolah-daring-kpai-surati?page=all/ 23 Oktober 2020/26 Oktober 2020, pk. 19.40.
} 
siswa, maka akan didapatkan jalan terang atas segala kendala yang muncul selama berjalannya pembelajaran daring. Orang tua/ wali siswa juga akan mendapatkanpengarahan bagaimana sikap yang seharusnya ditanamkan oleh orang tua/ wali dalam melakukan pendampingan anak ketika belajar di rumah. Oleh karena berbagai kendala yang mungkin saja terjadi, maka perlu diadakannya sosialisasi pihak sekolah bersama wali murid/ orang tua siswa.

Sebelum pandemi Covid-19 mulai menyebar, anak-anak melakukan pola belajar dengan semangat dikarenakan bertemu langsung dengan gurunya dan juga teman-temannya. Peserta didik juga saling bertanya, saling menyapa, saling mendukung, dan saling mengingatkan untuk melakukan pola keseharian dengan baik. Contohnya: siswa ditanya jam berapa mereka bangun tidur, apakah siswa melakukan sholat subuh,dan kemudian ditanya mengenai hafalan mereka. Karena hal tersebut akan membentuk pola keseharian yang baik. Hal yang sangat penting adalah hafalan al-Quran, ini harus dijaga karena jika kita menghafal maka kita akan mendapatkan banyak pahala. Biasanya siswa mendapatkan motivasimotivasi dari ustadz/ ustadzahnya saat pembelajaran luring.

Terkadang peserta didik melakukan hal-hal yang bisa membuat mereka nyaman saat pembelajaran daring misalnya izin dengan mematikan kameranya entah mereka ke toilet, makan, dan lainnya. Sehingga mereka dapat menikmati suasana belajar mereka tersebut dengan caranya sendiri. Ketika pembelajaran di rumah, peserta didik meminta bantuan kepada orang tua agar segala sesuatunya bisa terkendali dengan baik oleh peserta didik. Jika peserta didik menyimak pembelajaran dengan baik, maka biasanya mereka melakukan tugas secara tersendiri. Dengan adanya pembelajaran jarak jauh ini, menjadikan orang tua dan anak tetap merasa dekat. Koordinasi pihak sekolah/ guru yang mengajar sudah menjadi kewajiban rutinitas. Terutama untuk wali kelas, hal yang perlu diutamakan, yaitu menanyakan kepribadian anak, mulai dari pola pikir dan pola sikapnya serta daya serap anak ketika menerima materi-materi pembelajaran terutama 
Unik Hanifah Salsabila, Naufal Fauzi Ramadhan, Mutia Eka Putri, Nurjannah, Gita Dwi Jayanti

Penggunaan Teknologi Pendidikan dalam Pembelajaran Jarak Jauh

tsaqofah Islam (kegiatan keseharian yang berbau agama). Menurut Richardus Eko Indrajit, saat mengisi salah satu seminar Nasional di Jakarta, "Teknologi tidak akan bisa menggantikan guru, tapi guru yang tidak menggunakan teknologi akan tergantikan. Karena itu, guru harus senantiasa belajar sepanjang hayatnya karena jika seorang guru berhenti belajar, dia sejatinya berhenti menjadi guru." ${ }^{21}$ Karena bagaimanapun teknologi hanyalah sebatas perangkat dan yang dapat mengendalikannya hanyalah manusia, khususnya dalam bidang pendidikan yang dapat mengendalikannya yakni pendidik maupun peserta didik.

\section{SIMPULAN}

Berdasarkan hasil pembahasan temuan diatas, maka dapat disimpulkan: (1) Pelaksanaan pembelajaran Pembelajaran Jarak Jauh di Masa Pandemi Covid-19 untuk siswa SD dan MI selama pembelajaran virtual yaitu: Zoom Cloud Meeting, Google Classroom serta Whatsapp group untuk pengumpulan tugas dan presensi kehadiran siswa. (2) Permasalahan yang terjadi pada saat proses pembelajaran jarak jauh adalah adanya kendala sinyal yang kurang bagus dan terkadang siswa merasa bosan ketika sedang melakukan pembelajaran daring sehingga mereka sambil bermain, tiduran, dan memakan cemilan. (3) Solusi yang dilakukan oleh guru untuk mengatasi permasalahan tersebut adalah dengan memberi weekend project di hari Sabtu dan Ahad.

\footnotetext{
${ }^{21}$ Dhika Kusuma Winata, Era Revolusi Teknologi,Peran Guru Tetap Tidak Tergantikan, dalam https://mediaindonesia.com/read/detail/212578-era-revolusi-teknologi-peran-gurutetap-tidak-tergantikan 24 Januari 2020/30 Oktober 2020 pk. 22.20 WIB
} 


\section{DAFTAR PUSTAKA}

Abdullah, Burhanudin. Menanti Kemakmuran Negeri. Jakarta: PT. Gramedia pustaka utama, 2006.

Arsyad, Azhar. Media Pembelajaran. Jakarta: PT. Raja Grafindo Persada, 2013.

Munir. Pembelajaran Jarak Jauh Berbasis Teknologi Informasi dan Komunikasi. Bandung: Alfabeta, 2009.

Nasution. Teknologi Pendidikan. Jakarta: Bumi Aksara, 2005.

Rusman, dkk.Pembelajaran Berbasis Teknologi Informasi Dan Komunikasi, Mengembangkan Profesionalitas Guru.ed.1, cet. Ke-4.Jakarta: Rajawali pers, 2015.

Karo-Karo, Isran Rasyid, S dan Rohani, Manfaat Media Dalam Pembelajaran, Jurnal AXIOM: Vol. VII, No. 1, Januari-Juni 2018.

Rosali, Ely Satiyasih . Aktifitas Pembelajaran Daring Pada Masa Pandemi Covid-19 di Jurusan Pendidikan Geografi Universitas Siliwangi Tasikmalaya. Geography Science Education Journal (GEOSEE), volume 1 Nomor 1 Bulan Juni Tahun 2020.

Dwi C, Briliannur dkk. Analisis Keefektifan Pembelajaran Online di Masa Pandemi Covid-19. Jurnal MAHAGURU: Jurnal Pendidikan Guru Sekolah Dasa, vol 2 No 12020.

Budiman, Hari. Peran Teknologi Informasi Dan Komunikasi Dalam Pendidikan. Al-Tadzkiyyah: Jurnal Pendidikan Islam, Volume 8 No. I. 2017.

Dolong, H.M. Jufri. Teknik Analisis Dalam Komponen Pembelajaran. Jurnal Inspiratif Pendidikan. Volume 5 Nomor 2, Juli-Desember 2016.

Hadiwardoyo, Widodo. Kerugian Ekonomi Nasional Akibat Pandemi Covid-19. Jurnal of Business and Entrepreneurship. Volume 2 Nomor 2, April 2020.

Rigianti, Henry Aditia. Kendala Pembelajaran Daring Guru Sekolah Dasar di Kabupaten Banjarnegara. Jurnal Elementary School. Volume 7 Nomor 2, Juli 2020. 
Unik Hanifah Salsabila, Naufal Fauzi Ramadhan, Mutia Eka Putri, Nurjannah, Gita Dwi Jayanti

Penggunaan Teknologi Pendidikan dalam Pembelajaran Jarak Jauh

Tafonao, Talizaro. Peranan Media Pembelajaran Dalam Meningkatkan Minat Belajar Mahasiswa. Jurnal Komunikasi Pendidikan, Vol.2 No.2, Juli 2018.

Umar. MEDIA PENDIDIKAN: Peran dan Fungsinya dalam Pembelajaran. Jurnal Tarbawiyah Volume 11 Nomor 1 Edisi Januari-Juli 2014.

Mashabi, Sania. Siswi Bunuh Diri Diduga Depresi karena Tugas Sekolah Daring, KPAI Surati Kemendikbud dalam https://nasional.kompas.com/read/2020/10/23/15110441/siswibunuh-diri-diduga-depresi-karena-tugas-sekolah-daring-kpaisurati?page $=$ all 23 Oktober 2020/ 26 Oktober 2020 pk. 19.40

Winata, Dhika Kusuma. Era Revolusi Teknologi, Peran Guru Tetap Tidak Tergantikan, dalam https://mediaindonesia.com/read/detail/212578era-revolusi-teknologi-peran-guru-tetap-tidak-tergantikan 24 Januari 2020/ 30 Oktober 2020 pk. 22.20

Rahmawati, Kholiq. Wawancara, Balikpapan, 28 Oktober 2020.

Kumalasary, Dyah Astuti Ningrum dan Velatiani, Bredha.Wawancara, Balikpapan, 28 Oktober 2020. 